\title{
Contamination, parasitism and condition of Anguilla anguilla in three Italian stocks
}

\author{
Silvia Quadroni · Silvana Galassi · Fabrizio Capoccioni • \\ Eleonora Ciccotti · Gilberto Grandi • \\ Giulio A. De Leo $\cdot$ Roberta Bettinetti
}

Accepted: 2 October 2012

(c) Springer Science+Business Media New York 2012

\begin{abstract}
In conjunction with habitat loss and overfishing, pollution and parasitism are believed to be relevant causes of collapse of Anguilla, as these can affect eel swimming ability and the development of gonads and embryos. The present study investigated Persistent Organic Pollutant (POP) concentrations, infection levels of Anguillicoloides crassus, lipid content and gonad abnormalities in eels sampled in 2007-2008 in three Italian water bodies (Caprolace Lake, Lesina Lagoon and Tevere River) that vary in salinity, trophic condition, contamination level and fishing pressure. Our analysis revealed that low-to-moderate levels of contamination and parasitism were not associated with gonad abnormalities in Caprolace Lake and Lesina Lagoon. On the contrary, POP concentrations and abundances of swim bladder nematodes were remarkably high in eels from the heavily urbanized Tevere River and were associated with
\end{abstract}

Electronic supplementary material The online version of this article (doi:10.1007/s10646-012-1006-0) contains supplementary material, which is available to authorized users.

S. Quadroni $(\bowtie)$

Department of Theoretical and Applied Sciences (Environmental

Section), University of Insubria, Via Dunant 3,

21100 Varese, Italy

e-mail: silvia.quadroni@uninsubria.it

S. Galassi

Department of Biology, University of Milan, Via Celoria 26,

20133 Milan, Italy

F. Capoccioni - E. Ciccotti

Department of Biology, University of Rome "Tor Vergata",

Via della Ricerca Scientifica 1, 00133 Rome, Italy

G. Grandi

Department of Biology and Evolution, University of Ferrara,

Via L. Borsari 46, 44100 Ferrara, Italy significant gonad and swim bladder alterations. Contamination and infestation levels were so high to potentially impair spawner successful migration and reproduction. POP concentrations in Tevere eels also exceeded levels considered safe for food consumption. Though marginally contaminated, eels from the oligotrophic Caprolace Lake were in critical health condition: their lipid reserve was so low as to be considered insufficient to sustain the energetic costs of the transoceanic migration. Lesina eel stock was the only one displaying relatively good quality but here spawner abundance is likely limited by overfishing. Our results suggest that multiple stressors may potentially affect eel reproductive success. More definitive studies are needed to assess whether health effects caused by these multiple stressors are additive, compensatory or synergistic.

Keywords Anguilla anguilla POP bioaccumulation . Parasitism · Lipid content · Gonad alterations . Ecological and sanitary risk

\section{G. A. De Leo}

Hopkins Marine Station and Woods Institute for the Environment, Stanford University, Pacific Grove, CA, USA

G. A. De Leo

Department of Environmental Sciences, University of Parma, Viale Usberti 11/A, 43100 Parma, Italy

\section{R. Bettinetti}

Department of Theoretical and Applied Sciences (Environmental Section), University of Insubria, Via Dunant 3, 21100 Varese and Via Valleggio 11, 22100 Como, Italy 


\section{Introduction}

In recent years increased attention has been given to the decline in recruitment, stock and yield of the European eel (Anguilla anguilla L. 1758) in most European and North African inland and coastal waters. Since 2000, the number of glass eels ascending European rivers has decreased down to $1-5 \%$ of the pre-1980 levels (ICES 2007). A decrease in landings has also occurred, indicating a reduction of the continental stocks, possibly ten times lower than the pristine level (Feunteun 2002; Dekker 2003). In 2001 the International Council for the Exploration of the Sea (ICES) declared that eel status was below safe biological limits and that current harvesting rates were not sustainable (ICES 2001). In the following years, this led to several initiatives resulting in a number of measures aimed at eel conservation and sustainable management. In 2007, the European eel was listed in the Appendix II of the Convention on International Trade in Endangered Species (CITES 2007). In 2008 the International Union for Conservation of Nature (IUCN) included A. anguilla in the Red List as "critically endangered" (Freyhof and Kottelat 2008). The European Council Regulation 1100/2007 (EC 2007) demanded all Member States to adopt Eel Management Plans (EMPs) aimed at progressively removing the main causes of eel decline so as to guarantee the migration toward the sea of at least $40 \%$ of the silver eel biomass from each catchment basin, with respect to reference conditions defined by the absence of anthropogenic impacts.

Besides a reduction in spawner abundance caused by overfishing and habitat loss, an additional driver of eel collapse could be a reduction in spawner quality due to infections by viruses and parasites and pollution by inorganic and organic chemicals (Belpaire et al. 2011a). The exotic nematode Anguillicoloides crassus can cause swim bladder dysfunction and thus influence the migration of mature eels (Möller et al. 1991; Sjoberg et al. 2009). The high lipid content, long life span, low depuration rate and autoecology of this semelparous carnivore species with benthic and rather sedentary behaviour (Larsson et al. 1991; Tesch 2003) make the European eel particularly prone to lipophilic contaminant accumulation with respect to other fish. Contamination by Persistent Organic Pollutants (POPs) in particular may affect eel physiology, migration and reproductive success (Geeraerts and Belpaire 2010).

So far only a small number of studies is focused on the joint effects of pollutants and parasites on eel health (Sures and Knopf 2004; Sures 2006; Sures et al. 2006). This is an area that requires further investigation, as contaminant exposure can lead to a decrease in growth or impair the physiology of the immune system, causing an increased sensitivity to infectious diseases and parasites. On the other hand, some parasites may bioconcentrate specific contaminants (Tenora et al. 1999; Eira et al. 2009), suppressing the detrimental effect of these chemicals on eel, or could influence the metabolism of pollutants (Geeraerts and Belpaire 2010). Pollution and parasites can thus interact in either synergistic or antagonistic ways (Sures 2006).

In 2007, the Working Group On Eels started the set up of the European Eel Quality Database to collect recent data on lipid content, body burden of chemicals—such as polychlorinated biphenyls (PCBs) and organochlorine pesticides (OCPs) - and epidemiological parameters such as infection level of A. crassus (Belpaire et al. 2011a). While a remarkable quantity of field evidence regarding eel contamination has been gathered in Central and Northern Europe (Macgregor et al. 2010; Belpaire et al. 2011b), information is still scarce and incomplete for eels from the Mediterranean countries (ICES 2011). In the case of France, Spain and Italy, only few works have been recently published about the status of local eel stocks (Bordajandi et al. 2003; Buet et al. 2006; Ferrante et al. 2010) and little is known about the past decades (Bressa et al. 1997). A. crassus has been extensively monitored in the Camargue Lagoon and in other Mediterranean inland and coastal waters (Lefebvre et al. 2002, 2003; Lefebvre and Crivelli 2004; Maillo et al. 2005; Genc et al. 2005; Esteve and Alcaide 2009). Other than a few notable exceptions, the quality of eels fished and farmed in the coastal areas of the rest of the Southern Europe and Northern Africa is almost unknown (Maamouria et al. 1999; Rahhou et al. 2001; Gargouri Ben Abdallah and Maamouria 2006).

In a previous work, Bettinetti et al. (2011) reported the levels of PCBs, DDTs (dichlorodiphenyltrichloroethane), HCHs (hexachlorocyclohexanes) and HCB (hexachlorobenzene) in eels collected from three different water bodies in Italy (Caprolace Lake, Lesina Lagoon and Tevere River) to investigate the possible use of this species for POP biomonitoring in European aquatic ecosystems. In this study we integrated the dataset used by Bettinetti et al. (2011) with contamination data from additional eel specimens and extended the POP analysis to other chlorinated compounds, i.e. $\beta-\mathrm{HCH}$, dioxins, furans and dioxin-like PCBs (DL-PCBs). Moreover, we used the same specimens to investigate the abundance of $A$. crassus and the degree of gonad alteration. The goal of this study was twofold. First, we wanted to present an updated and comprehensive analysis of contamination and infection levels of $A$. anguilla in three Italian coastal environments that vary for natural factors (i.e. salinity and primary production) and anthropogenic pressures associated with a wide range of farming, fishing and industrial activities. Second, we intended to assess potential effects on eel health by analysing possible associations between pollution, parasitism, lipid content, condition, swim bladder damage and 
reproductive organ alterations. On the basis of these results, we discussed whether the observed levels of contamination and infection may reduce eel reproductive success either directly by affecting gonad development or indirectly by impairing eel migration to the spawning area. Finally, we elaborated on the possible risk to human health caused by eel consumption, as the widespread use of $A$. anguilla as a gastronomic delicacy in many traditional recipes in Europe may represent an important pathway of human exposure to POPs (Harrad and Smith 1999)—many of which are considered potential carcinogens (Miller and Sharpe 1998).

\section{Materials and methods}

Study area and sample collection

Samplings were carried out on three coastal water bodies in Central-Southern Italy (Fig. 1) with different levels of salinity and human mediated pressures. Eels were collected randomly in all sites among commercial fishery catches with fyke netting (mesh size $10 \mathrm{~mm}$ ).

In February-March 2008, 22 eels were caught in Caprolace Lake (Latium; length $=3.7 \mathrm{~km}$; mean width $=$ $0.6 \mathrm{~km}$; area $=2.3 \mathrm{~km}^{2}$; mean depth $=1.3 \mathrm{~m}$; maximum depth $=2.9 \mathrm{~m}$; salinity $=34.6-41.1 \%$; water temperature $=8.7-29.1^{\circ} \mathrm{C} ;$ Fig. $1 ; 41^{\circ} 21^{\prime} \mathrm{N}-12^{\circ} 59^{\prime} \mathrm{E}$ ), located within Circeo National Park in the Tyrrhenian coast between two other coastal lakes. These lakes are the remnants of a reclamation performed in the 1930s and were declared "Wetlands of International Importance" under the Ramsar Convention in 1978. In the early 1980s, freshwater inputs were cut off due to high levels of nutrients flowing in Caprolace Lake from the surrounding area, where intensive agriculture as well as cattle farming is present. The lake is connected to the sea by one artificial channel (250 m long) and has artificial banks. The park authority exerted moderate fishing pressure until 2007, after which any exploitation of the local eel stock was prohibited.

In October-December 2007, 28 eels were caught in Lesina Lagoon (Apulia; length $=22.2 \mathrm{~km}$; mean width $=$ $2.5 \mathrm{~km}$; area $=51.4 \mathrm{~km}^{2}$; mean depth $=0.7 \mathrm{~m}$; maximum depth $=1.5 \mathrm{~m}$; salinity $=10.6-28.4 \%$; water temperature $=9.0-27.0^{\circ} \mathrm{C} ;$ Fig. $1 ; 41^{\circ} 53^{\prime} \mathrm{N}-15^{\circ} 51^{\prime} \mathrm{E}$ ), located within Gargano National Park along the Adriatic coast. The lagoon is connected to the sea by two artificial tidal channels (3 and $0.8 \mathrm{~km}$ long), endowed with sluices to regulate water exchanges. The catchment basin $\left(460 \mathrm{~km}^{2}\right)$ includes some livestock farms as well as seed and irrigated crops. Several fish farm treated waters and the partially treated urban waste waters of three municipalities, with a cumulated population amounting to 30,000 inhabitants, flow into the lagoon. The salinity variations are pronounced and show a permanent $\mathrm{E}-\mathrm{W}$ gradient due to the freshwater inputs in the eastern part of the lagoon. Eel fishing is a
Fig. 1 Study area and sampling stations: Caprolace Lake, Lesina Lagoon and Tevere River

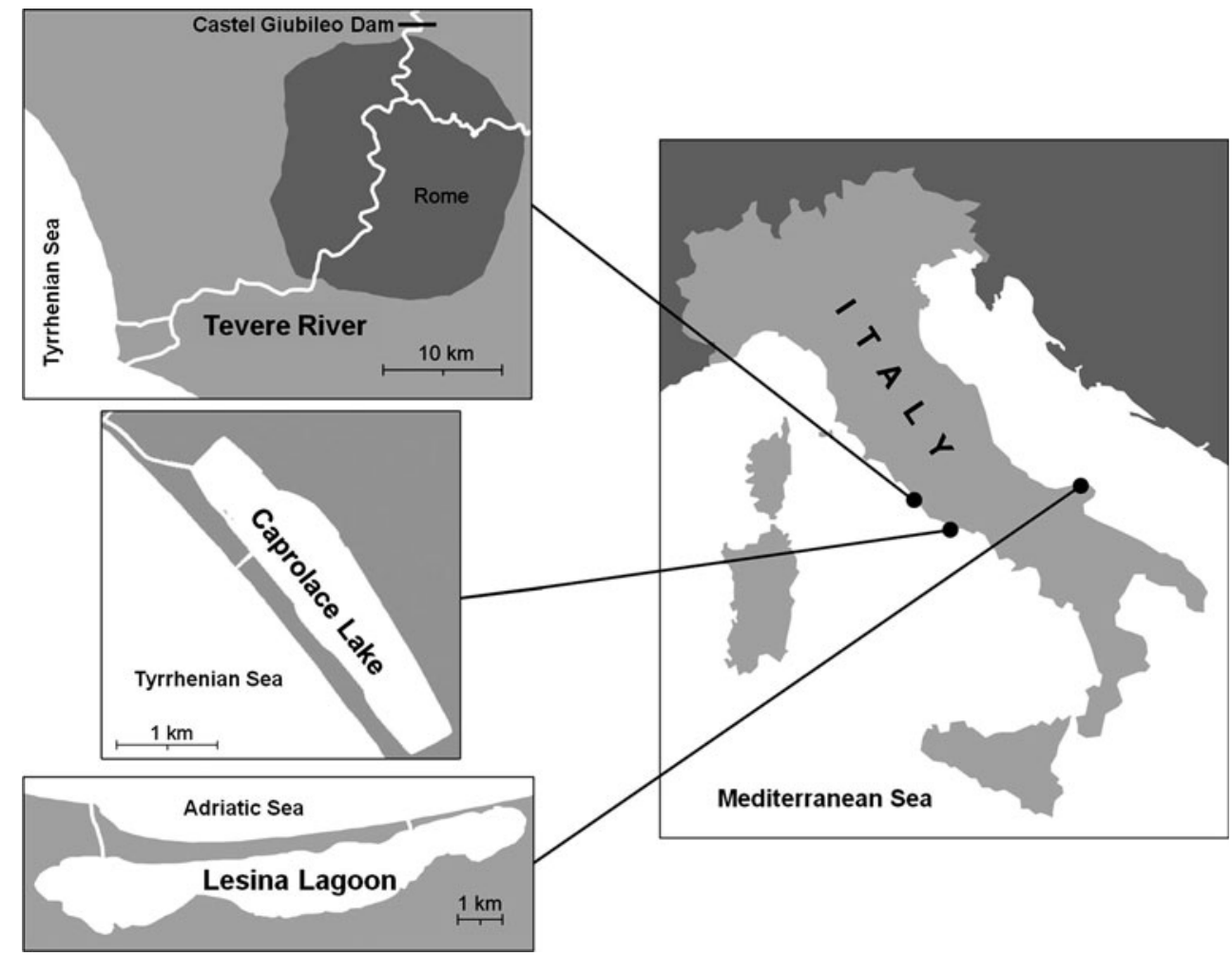


traditional activity, carried out with particular net setting, called paranza. Most of the catch occurs between October and March and is composed of migrating silver eels, which are sold for direct consumption.

In October-November 2007, 24 eels were caught at $20 \mathrm{~km}$ from the mouth of Tevere River (Latium; length $=405 \mathrm{~km}$; catchment area $=17,375 \mathrm{~km}^{2}$; water temperature $=10.0-23.7^{\circ} \mathrm{C} ;$ Fig. $1 ; \quad 41^{\circ} 48^{\prime} \mathrm{N}-12^{\circ} 25^{\prime} \mathrm{E}$ ). The dam of Castel Giubileo, located upstream from the city of Rome, represents the first obstacle to the upward migration of eels. Between this dam and the mouth there is the Aniene inlet, an important eel reservoir and a source of pollution that, along with the high urbanization of Rome and many industries, exerts a high pressure on the lower Tevere River. In this stretch the fishery mainly targets yellow eels less than $40 \mathrm{~cm}$ long that are sent to aquaculture facilities.

Each individual was anaesthetized with 2-phenoxyethanol $1 \%$, painlessly killed, weighed and measured. Otoliths were extracted, embedded in a low viscosity resin and stained with $3 \%$ toluidine blue following grinding of the convex side (ICES 2009). Individual age was determined from reading annual otolith rings (annuli) starting from the first ring after the marine nucleus edge using a light stereomicroscope. The assigned age of the animal corresponds to the number of years of colonization from the continental water body. The developmental stage was assigned on the basis of livery (yellow or silver eel) and confirmed by the Ocular Index (OI) calculated according to Pankhurst (1982). Sex was macroscopically assessed whenever possible by gonad examination during dissection according to Colombo et al. (1984). Alternatively, sex was determined by histological analysis of the gonad structure according to previously established criteria of gonad differentiation (Colombo and Grandi 1996; Grandi and Colombo 1997). Fulton's condition factor $(\mathrm{K})$ was calculated according to the equation $\mathrm{W}^{*} 100 / \mathrm{L}^{3}$, where $\mathrm{W}$ is the weight expressed in $\mathrm{g}$ and $\mathrm{L}$ the length in $\mathrm{cm}$ (Nash et al. 2006).

\section{Chemical analysis}

Due to budget limitations eels less than $40 \mathrm{~cm}$ long from Lesina Lagoon and Tevere River were pooled in two size classes for POP analysis, i.e. a first pool for eels smaller than $30 \mathrm{~cm}$ ( $n=5$ and 9, respectively) - mostly young and undifferentiated eels-and a second pool for eels between 30 and $40 \mathrm{~cm}(n=13$ and 8 , respectively -mostly sexually differentiated yellow and silver eels. Eels over $40 \mathrm{~cm}$ from Lesina Lagoon and Tevere River and all Caprolace specimens, regardless of their size, were individually analyzed.

All the animals were stored frozen at $-20^{\circ} \mathrm{C}$; a portion of the dorsal muscle tissue above the gastrointestinal cavity was freeze-dried and homogenized. $0.5 \mathrm{~g}$ of each sample (either from a single fish or a pool) were extracted with $50 \mathrm{~mL}$ of an acetone- $n$-hexane (pesticide analysis grade, Carlo Erba, Italy) 1:1 (v/v) mixture in glass microfibre thimbles $(19 \times 90 \mathrm{~mm}$, Whatman, England $)$ using a modified Soxhlet apparatus (Velp Scientifica, ECO 6 Thermoreactor, Italy). The gravimetric determination of lipids was performed after solvent evaporation. Lipids were suspended in $2 \mathrm{~mL}$ of $n$-hexane and destroyed with $5 \mathrm{~mL}$ of $\mathrm{H}_{2} \mathrm{SO}_{4}$ (98\%, Carlo Erba, Italy). Chlorinated compounds were then recovered by several $n$-hexane washings. Hexane extracts were concentrated under vacuum to about $2 \mathrm{~mL}$ and cleaned-up on a Florisil column $(7 \times 40 \mathrm{~mm}$, Merck, Germany), eluting with $25 \mathrm{~mL}$ of a $n$-hexanedichloromethane (pesticide analysis grade, Carlo Erba, Italy) $85: 15(\mathrm{v} / \mathrm{v})$ mixture according to a procedure used in an intercalibration exercise (Galassi et al. 1981). The purified extracts $(1 \mu \mathrm{L})$ of each sample were introduced by on-column injection into a gas chromatograph (TOP 8000, Carlo Erba, Italy) equipped with a capillary column $(50 \mathrm{~m} \times 0.25 \mathrm{~mm}$, film thickness $0.25 \mu \mathrm{m}$, WCOT fused silica CP-Sil 8CB, Varian, USA) and a ${ }^{63} \mathrm{Ni}$ electron capture detector (ECD 80, ThermoQuest Carlo Erba, Italy), heated at $320{ }^{\circ} \mathrm{C}$. The temperature program used was: from 60 to $180{ }^{\circ} \mathrm{C}$ at $20^{\circ} \mathrm{C} / \mathrm{min}$, followed by a run from 180 to $200{ }^{\circ} \mathrm{C}$ at $1.5^{\circ} \mathrm{C} / \mathrm{min}$, a further run from 200 to $270{ }^{\circ} \mathrm{C}$ at $3{ }^{\circ} \mathrm{C} / \mathrm{min}$, and a final isotherm at $270{ }^{\circ} \mathrm{C}$ for $20 \mathrm{~min}$, with helium as carrier gas $(1 \mathrm{~mL} / \mathrm{min})$ and nitrogen as auxiliary gas $(30 \mathrm{~mL} / \mathrm{min})$. For OCP quantification an external standard was prepared with pure compounds (Pestanal, Sigma-Aldrich, Germany) dissolved in iso-octane (pesticide analysis grade, Carlo Erba, Italy), while for PCB quantification Aroclor 1260 (Alltech, USA) with the addition of PCB 28, 52 and 118 was used. The sum of PCB $28,52,101,118,138,153$ and 180 is reported as indicator PCBs since these 7 congeners are the most representative on the basis of their persistence in food webs and tendency for bioaccumulation.

Good laboratory practices were tested on the standard reference materials BCR-598 and BCR-349 (Community Bureau of Reference, Belgium) for OCP and PCB residues, respectively, analysing samples in triplicate. The percentage of recovery of $\mathrm{pp}^{\prime} \mathrm{DDE}$ (1,1'-dichloro-2,2'-bis-(4-chlorophenyl)-ethylene) was $107.5( \pm 4.0 \%)$, of pp'DDD $\left(1,1^{\prime}-\right.$ dichloro-2,2'-bis-(4-chlorophenyl)-ethane) $106.2( \pm 4.0 \%)$, of $\mathrm{pp}^{\prime}$ DDT (1,1,1-trichloro-2,2-bis-(4-chlorophenyl)-ethane) $106.2( \pm 3.0 \%)$, of HCB $105.2( \pm 9.9 \%)$, of $\mathrm{HCHs}$ varied between $89.5( \pm 9.1 \%)$ and $107.7( \pm 7.2 \%)$ and of PCBs between $91.3( \pm 1.1 \%)$ and $102.2( \pm 1.6 \%)$. The detection limit was $0.01-0.05 \mathrm{ng} / \mathrm{g}$ wet weight (w.w.) or $0.1-0.5 \mathrm{ng} / \mathrm{g}$ lipids (lip.) depending on the chlorinated compound.

Polychlorinated dibenzodioxins (PCDDs), polychlorinated dibenzofurans (PCDFs) and DL-PCBs were determined in three silver eels for each study site by High 
Resolution Gas Chromatograph/Mass Spectrometer (HRGC/MS) (these analysis were performed by the accredited Laboratory of Environmental Chemistry and Toxicology, Mario Negri Institute for Pharmacological Research, Milan, Italy). The detection limit was 0.10$0.58 \mathrm{pg} / \mathrm{g}$ w.w. depending on the dioxin-like compound. World Health Organization-Toxic Equivalent Factors (WHO-TEFs) for human (van den Berg et al. 2006) were used for calculating Toxic Equivalents (TEQs) with respect to 2,3,7,8-TCDD (2,3,7,8-tetrachlorodibenzodioxin).

Parasitology investigation

Each individual was dissected and the swim bladder was removed, maintained damp in distilled water and dissected in a longitudinal sense to identify and single count $A$. crassus nematodes using a binocular stereomicroscope. Parasites were weighted and the swim bladders were analyzed in order to detect the presence of encapsulated larvae in the wall. Classical epidemiological parameters-i.e. prevalence (percentage of infected individuals on the total examined eels), abundance (number of parasites in a specimen) and mean intensity (average number of parasites in the infected eels)—were calculated according to Bush et al. (1997) for each sampling site. Following Székely et al. (2005), we computed the infection level as the ratio between the parasite total weight and the eel weight $(\mathrm{Wp} /$ $\mathrm{W})$. The relative swim bladder length or Length Ratio Index (LRI), computed as the ratio between the swim bladder length and the eel length $(\mathrm{Ls} / \mathrm{L})$, was used for establishing the degree of the mechanical swim bladder damage: the smaller LRI, the higher the damage (Lefebvre et al. 2011).

\section{Gonad investigation}

Gonads were histologically examined to assess their developmental stage and identify possible alterations. Small pieces from the cephalic, medial and caudal regions of the gonads were removed from the body after eel dissection, fixed in Bouin's fluid for $24 \mathrm{~h}$ and stored in $70 \%$ ethanol. The fixed tissue was dehydrated through a series of graded ethanol solutions and embedded in Paraplast. Cross sections $7-\mu \mathrm{m}$ thick were mounted on glass slides, stained by Papanicolaou with eosin-hematoxylin solution (Merck, Germany) and examined by a Leitz Aristoplan (Ernst Leitz Wetzlar GmbH, Germany) photomicroscope equipped with a Nikon Digital Sight DS-5 M camera (Nikon Corp., Japan).

The extent of gonad alteration was determined after examining 348 eels: 99 (length: $18.5-67.5 \mathrm{~cm}$ ) were caught in Caprolace Lake, 100 (length: $25.5-72.5 \mathrm{~cm}$ ) in Lesina Lagoon and 149 (length: $20.5-56.0 \mathrm{~cm}$ ) in Tevere River. The scale of gonad alteration was established on the basis of several previous studies on gonad development and differentiation (Colombo et al. 1984; Colombo and Grandi 1995; Colombo and Grandi 1996; Grandi and Colombo 1997; Grandi et al. 2000).

Here follows a detailed description of the classes of Gonad Alteration Level (GAL):

0 -no alteration detectable (Fig. 4a, b).

1 -slight alterations (some germ cells showing degenerations, easily detected by their pycnotic nucleus and slightly stained cytoplasm) (Fig. 4c).

2-medium (extended degenerations of somatic and germ cells, with appearance of some areas of necrotic and adipose tissues) (Fig. $4 \mathrm{~d}$, e).

3-high (extended hypertrophy of the connective tissue, reduced number of germ cells and loss of the normal histological organization) (Fig. 4f).

\section{Statistical analysis of data}

One-way ANOVA with Scheffè's test or $t$ test were applied to compare morpho-physiological characteristics of eels from the three study sites and/or with different sex and stage. Possible correlations between morpho-physiological characteristics, POP levels (expressed both on w.w. and on lip.) and parasite or gonad alteration indexes were investigated using Pearson $(r)$ test or Spearman $(\rho)$ test if an ordinal variable was present. A principal component analysis (PCA) was performed considering only samples individually analyzed for POP determination as objects and contaminants, eel weight and lipid content as variables. After that data on contamination were $\log (x+1)$-transformed to obtain a Gaussian distribution, one-way ANOVA with Scheffè's test was applied to compare POP concentrations on lipid basis in eels from the three study sites. All the statistical analysis were performed using STATISTICA (version 8) software. Tests were considered significant for $p<0.05$.

\section{Results}

The samples collected in the three Italian coastal environments exhibited a different composition for size (ANOVA, $p<0.05$ ), sex ratio ( $\hat{o}^{\circ}:$ ? $)$ and age classes (ANOVA, $p<0.05$ ) as shown in Table 1. Length was correlated with age in each site (Caprolace Lake: $n=22$, $r=0.61$; Lesina Lagoon: $n=28, r=0.82$; Tevere River: $n=24, r=0.79 ; p<0.05)$. Caprolace eels were older than Tevere ones, while Lesina eels were the youngest (ANOVA, $p<0.05$ ). No significant difference among samples was found for the condition factor (Table 1). K was correlated with age $(n=28, r=0.63, p<0.05)$ and 
Table 1 Morphometric and physiological characteristics, POP mean concentrations \pm SD (min-max) and number of infected samples by A. crassus of eels from Caprolace Lake, Lesina Lagoon and Tevere River divided in three length classes

\begin{tabular}{|c|c|c|c|c|c|c|c|c|c|c|c|c|c|}
\hline \multirow{2}{*}{$\frac{\text { Length classes }}{\text { Caprolace Lake }}$} & \multirow[t]{2}{*}{$n$} & Length $(\mathrm{cm})$ & \multicolumn{2}{|l|}{ Weight (g) } & \multicolumn{2}{|l|}{$\mathrm{K}$} & \multirow[t]{2}{*}{ Stage } & \multirow[t]{2}{*}{ Age (years) } & \multirow[t]{2}{*}{ Sex } & \multicolumn{2}{|c|}{ Lipids (\%) } & \multicolumn{2}{|c|}{ PCBs (ng/g w.w.) } \\
\hline & & \multirow[b]{2}{*}{$\begin{array}{l}26.11 \pm 4.01 \\
(18.5-30.0)\end{array}$} & \multirow{2}{*}{\multicolumn{2}{|c|}{$\begin{array}{l}26.91 \pm 12.26 \\
(8.5-44.3)\end{array}$}} & & & & & & & & & \\
\hline$<30 \mathrm{~cm}$ & 7 & & & & \multicolumn{2}{|c|}{$\begin{array}{l}0.14 \pm 0.02 \\
(0.12-0.17)\end{array}$} & $7 y$ & $\begin{array}{l}6.00 \pm 1.63 \\
(4-9)\end{array}$ & $\begin{array}{l}2 \text { un } \\
4 S \\
1 \hat{\sigma}\end{array}$ & \multicolumn{2}{|c|}{$\begin{array}{l}5.51 \pm 4.62 \\
(0.51-11.63)\end{array}$} & \multicolumn{2}{|c|}{$\begin{array}{l}10.53 \pm 4.58 \\
(4.70-18.47)\end{array}$} \\
\hline $30-40 \mathrm{~cm}$ & 7 & $\begin{array}{l}35.91 \pm 1.02 \\
(35.0-38.0)\end{array}$ & \multicolumn{2}{|c|}{$\begin{array}{l}67.55 \pm 12.00 \\
(45.6-81.3)\end{array}$} & \multicolumn{2}{|c|}{$\begin{array}{l}0.14 \pm 0.02 \\
(0.11-0.18)\end{array}$} & $\begin{array}{l}3 y \\
4 s\end{array}$ & $\begin{array}{l}7.14 \pm 1.35 \\
(5-9)\end{array}$ & $\begin{array}{l}5 \hat{\circ} \\
2 \text { 平 }\end{array}$ & \multicolumn{2}{|c|}{$\begin{array}{l}10.77 \pm 7.39 \\
(0.33-17.52)\end{array}$} & \multicolumn{2}{|c|}{$\begin{array}{l}42.91 \pm 54.07 \\
(8.93-161.02)\end{array}$} \\
\hline$>40 \mathrm{~cm}$ & 8 & $\begin{array}{l}50.24 \pm 8.05 \\
(40.5-60.0)\end{array}$ & \multicolumn{2}{|c|}{$\begin{array}{l}202.24 \pm 102.20 \\
(91.0-360.3)\end{array}$} & \multicolumn{2}{|c|}{$\begin{array}{l}0.15 \pm 0.02 \\
(0.11-0.19)\end{array}$} & $\begin{array}{l}5 y \\
3 \mathrm{~s}\end{array}$ & $\begin{array}{l}8.38 \pm 2.13 \\
(5-11)\end{array}$ & 8 우 & \multicolumn{2}{|c|}{$\begin{array}{l}6.30 \pm 6.83 \\
(0.49-15.96)\end{array}$} & \multicolumn{2}{|c|}{$\begin{array}{l}21.56 \pm 22.75 \\
(6.71-72.75)\end{array}$} \\
\hline \multicolumn{14}{|l|}{ Lesina Lagoon } \\
\hline$<30 \mathrm{~cm}^{\mathrm{a}}$ & 5 & $\begin{array}{l}28.50 \pm 1.00 \\
(27.0-29.5)\end{array}$ & $\begin{array}{l}31.04 \pm 3.1 \\
(27.2-35.3)\end{array}$ & & $\begin{array}{l}0.13 \pm 0 \\
(0.12-0.1\end{array}$ & & $5 y$ & $\begin{array}{l}3.40 \pm 1.34 \\
(2-5)\end{array}$ & $5 \mathrm{~S}$ & 10.90 & & 7.95 & \\
\hline $30-40 \mathrm{~cm}^{\mathrm{a}}$ & 13 & $\begin{array}{l}34.94 \pm 2.83 \\
(30.0-39.0)\end{array}$ & $\begin{array}{l}65.14 \pm 18 \\
(39.6-97.6)\end{array}$ & & $\begin{array}{l}0.15 \pm 0 \\
(0.12-0.1\end{array}$ & & $13 y$ & $\begin{array}{l}3.46 \pm 0.78 \\
(2-5)\end{array}$ & $\begin{array}{l}2 \mathrm{~S} \\
11 \text { 우 }\end{array}$ & 10.61 & & 8.16 & \\
\hline$>40 \mathrm{~cm}$ & 10 & $\begin{array}{l}58.83 \pm 10.2 \\
(42.0-72.5)\end{array}$ & $\begin{array}{l}399.24 \pm 2 \\
(89.0-762.0\end{array}$ & 4.98 & $\begin{array}{l}0.17 \pm 0 \\
(0.12-0.2\end{array}$ & & $\begin{array}{l}5 y \\
5 \mathrm{~s}\end{array}$ & $\begin{array}{l}5.90 \pm 1.20 \\
(4-8)\end{array}$ & 10 우 & $\begin{array}{l}18.10 \pm \\
(10.14-2\end{array}$ & $\begin{array}{l}5.14 \\
4.49)\end{array}$ & $\begin{array}{l}7.63= \\
(5.11-\end{array}$ & $\begin{array}{l}3.24 \\
5.11)\end{array}$ \\
\hline Tevere River & & & & & & & & & & & & & \\
\hline$<30 \mathrm{~cm}^{\mathrm{a}}$ & 9 & $\begin{array}{l}24.61 \pm 2.72 \\
(20.5-29.0)\end{array}$ & $\begin{array}{l}23.81 \pm 9 .( \\
(14.8-42.9)\end{array}$ & & $\begin{array}{l}0.15 \pm 0 \\
(0.13-0.1\end{array}$ & & $\begin{array}{l}8 \mathrm{y} \\
1 \mathrm{~s}\end{array}$ & $\begin{array}{l}4.22 \pm 0.67 \\
(3-5)\end{array}$ & $\begin{array}{l}3 \text { un } \\
5 S \\
1 \widehat{0}\end{array}$ & 10.86 & & 1453. & \\
\hline $30-40 \mathrm{~cm}^{\mathrm{a}}$ & 8 & $\begin{array}{l}34.80 \pm 3.40 \\
(30.4-39.0)\end{array}$ & $\begin{array}{l}75.99 \pm 26 \\
(39.4-115.3\end{array}$ & & $\begin{array}{l}0.17 \pm 0 \\
(0.14-0.2\end{array}$ & & $\begin{array}{l}4 y \\
4 s\end{array}$ & $\begin{array}{l}6.00 \pm 1.31 \\
(4-8)\end{array}$ & $\begin{array}{l}1 \text { un } \\
4 \mathrm{~S} \\
3 \hat{\jmath}\end{array}$ & 20.80 & & 277.30 & \\
\hline$>40 \mathrm{~cm}$ & 7 & $\begin{array}{l}45.43 \pm 5.56 \\
(40.0-56.0)\end{array}$ & $\begin{array}{l}170.99 \pm 6 \\
(107.4-312 .\end{array}$ & & $\begin{array}{l}0.18 \pm 0 \\
(0.16-0.2\end{array}$ & & $7 \mathrm{~s}$ & $\begin{array}{l}6.71 \pm 1.70 \\
(5-9)\end{array}$ & $\begin{array}{l}6 \hat{\bigcirc} \\
10\end{array}$ & $\begin{array}{l}24.13 \pm \\
(15.72-?\end{array}$ & $\begin{array}{l}7.32 \\
7.40)\end{array}$ & $\begin{array}{l}258.78 \\
(91.95\end{array}$ & $\begin{array}{l} \pm 146.44 \\
-476.58)\end{array}$ \\
\hline Length classes & $\begin{array}{l}\mathrm{pp}^{\prime} \mathrm{I} \\
\text { (ng/ }\end{array}$ & $\begin{array}{l}\text { DE } \\
\text { w.w.) }\end{array}$ & $\begin{array}{l}\mathrm{pp}^{\prime} \mathrm{DDD} \\
\text { (ng/g w.w.) }\end{array}$ & $\begin{array}{l}\mathrm{pp}^{\prime} \mathrm{D} \\
\text { (ng/ }\end{array}$ & $\begin{array}{l}\text { T } \\
\text { w.w.) }\end{array}$ & & $\begin{array}{l}\text { B } \\
\text { /g w.w.) }\end{array}$ & $\begin{array}{l}\alpha-\mathrm{HCH} \\
\text { (ng/g w.w.) }\end{array}$ & $\begin{array}{l}\beta-\mathrm{H} \\
\text { (ng/ }\end{array}$ & $\begin{array}{l}\mathrm{CH} \\
\text { g w.w.) }\end{array}$ & $\begin{array}{l}\gamma-\mathrm{HC} \\
\text { (ng/g }\end{array}$ & $\begin{array}{l}\text { H } \\
\text { w.w.) }\end{array}$ & $n$ infected \\
\hline Caprolace Lake & & & & & & & & & & & & & \\
\hline$<30 \mathrm{~cm}$ & $\begin{array}{l}19.5 \\
(9.1\end{array}$ & $\begin{array}{l} \pm 15.23 \\
-53.24)\end{array}$ & $\begin{array}{l}1.17 \pm 0.77 \\
(0.50-2.72)\end{array}$ & $\begin{array}{l}0.83 \\
(0.4 C\end{array}$ & $\begin{array}{l} \pm 0.48 \\
-1.74)\end{array}$ & & $\begin{array}{l}4 \pm 0.10 \\
4-0.34)\end{array}$ & $\begin{array}{l}0.09 \pm 0.05 \\
(0.05-0.16)\end{array}$ & & $\begin{array}{l} \pm 0.10 \\
4-0.35)\end{array}$ & $\begin{array}{l}0.05 \\
(0.01\end{array}$ & $\begin{array}{l} \pm 0.03 \\
-0.09)\end{array}$ & 0 \\
\hline $30-40 \mathrm{~cm}$ & $\begin{array}{l}18.5 \\
(8.5\end{array}$ & $\begin{array}{l} \pm 9.26 \\
-32.68)\end{array}$ & $\begin{array}{l}2.00 \pm 1.53 \\
(0.41-4.39)\end{array}$ & $\begin{array}{l}1.29 \\
(0.5\end{array}$ & $\begin{array}{l} \pm 0.82 \\
-2.57)\end{array}$ & & $\begin{array}{l}4 \pm 0.23 \\
3-0.56)\end{array}$ & $\begin{array}{l}0.16 \pm 0.10 \\
(0.04-0.28)\end{array}$ & $\begin{array}{l}0.46 \\
(0.0\end{array}$ & $\begin{array}{l} \pm 0.63 \\
3-1.76)\end{array}$ & $\begin{array}{l}0.07 \\
(0.02\end{array}$ & $\begin{array}{l} \pm 0.03 \\
-0.12)\end{array}$ & 0 \\
\hline$>40 \mathrm{~cm}$ & $\begin{array}{l}11.0 \\
(6.6\end{array}$ & $\begin{array}{l} \pm 4.49 \\
-20.76)\end{array}$ & $\begin{array}{l}1.00 \pm 0.46 \\
(0.42-1.66)\end{array}$ & $\begin{array}{l}1.43 \\
(0.2\end{array}$ & $\begin{array}{l} \pm 1.62 \\
-4.87)\end{array}$ & & $\begin{array}{l}1 \pm 0.19 \\
4-0.47)\end{array}$ & $\begin{array}{l}0.08 \pm 0.06 \\
(0.04-0.20)\end{array}$ & & $\begin{array}{c} \pm 0.22 \\
2-0.63)\end{array}$ & $\begin{array}{l}0.05 \\
(0.01\end{array}$ & $\begin{array}{l} \pm 0.04 \\
-0.12)\end{array}$ & 0 \\
\hline Lesina Lagoon & & & & & & & & & & & & & \\
\hline$<30 \mathrm{~cm}^{\mathrm{a}}$ & 45.3 & & 4.19 & 3.10 & & 1.3 & & 0.25 & 0.85 & & 0.15 & & 1 \\
\hline $30-40 \mathrm{~cm}^{\mathrm{a}}$ & 105 & & 14.98 & 8.42 & & 1.1 & & 0.34 & 1.04 & & 0.27 & & 3 \\
\hline$>40 \mathrm{~cm}$ & $\begin{array}{l}89.5 \\
(45\end{array}$ & $\begin{array}{l}5 \pm 74.84 \\
0-288.05)\end{array}$ & $\begin{array}{l}7.42 \pm 4.82 \\
(3.46-19.50)\end{array}$ & $\begin{array}{l}4.47 \\
(2.2\end{array}$ & $\begin{array}{l} \pm 2.48 \\
-10.95)\end{array}$ & & $\begin{array}{l}6 \pm 0.45 \\
55-2.07)\end{array}$ & $\begin{array}{l}0.30 \pm 0.15 \\
(0.14-0.67)\end{array}$ & & $\begin{array}{c} \pm 0.29 \\
7-1.25)\end{array}$ & $\begin{array}{l}0.12 \\
(0.03\end{array}$ & $\begin{array}{l} \pm 0.08 \\
-0.25)\end{array}$ & 3 \\
\hline Tevere River & & & & & & & & & & & & & \\
\hline$<30 \mathrm{~cm}^{\mathrm{a}}$ & 245 & & 32.76 & 37.0 & & 3.1 & & 0.37 & 1.48 & & 0.19 & & 5 \\
\hline $30-40 \mathrm{~cm}^{\mathrm{a}}$ & 207 & & 37.31 & 22.0 & & 5.4 & & 0.52 & 2.22 & & 0.16 & & 6 \\
\hline$>40 \mathrm{~cm}$ & $\begin{array}{l}110 \\
(43\end{array}$ & $\begin{array}{l}39 \pm 120.38 \\
4-38.66)\end{array}$ & $\begin{array}{l}25.96 \pm 15.20 \\
(11.22-57.72)\end{array}$ & $\begin{array}{l}15.5 \\
\left(9.0^{\prime}\right.\end{array}$ & $\begin{array}{l} \pm 10.66 \\
-38.09)\end{array}$ & & $\begin{array}{l}4 \pm 2.27 \\
0-9.39)\end{array}$ & $\begin{array}{l}0.92 \pm 0.69 \\
(0.35-2.38)\end{array}$ & & $\begin{array}{l} \pm 2.92 \\
9-10.08)\end{array}$ & $\begin{array}{l}0.25 \\
(0.19\end{array}$ & $\begin{array}{l} \pm 0.05 \\
-0.32)\end{array}$ & 6 \\
\hline
\end{tabular}

$n$ number of samples; $K$ Fulton's condition factor; stage: $y$ yellow, $s$ silver; sex: un undifferentiated, $S$ Syrski organ, ô male, $q$ female

${ }^{a}$ Samples analysed by pool 
lipid content $(n=10, r=0.63, p<0.05)$ in Lesina eels, while $\mathrm{K}$ was only correlated with fat percentage $(n=22$, $r=0.61, p<0.05$ ) in Caprolace eels.

Caprolace eels exhibited the highest variation in lipid content (Table 1): yellow eels had lower fat content than silver ones $(t$ test, $p<0.05)$. Both yellow and silver females from Caprolace Lake had lower lipid percentage than Lesina yellow and silver ones, respectively ( $t$ test, $p<0.05$ ), and silver males in Caprolace Lake had lower lipid content than those in Tevere River ( $t$ test, $p<0.05$ ).

Despite remarkable inter-site differences, PCBs and $\mathrm{pp}^{\prime}$ DDE provided the main contribution to eel contamination in all the sampling sites, followed by the other DDT homologues and, finally, by HCB and HCHs (Table 1). Positive correlations among all contaminants were observed $(p<0.05)$ with the occasional exception of POPs with concentrations near the detection limit. Eels from Tevere River were the most polluted in each of the three size classes (Table 1), especially those with a length $<30 \mathrm{~cm}$.

The first component of the PCA (Fig. 2) accounted for $54.19 \%$ of the variance in the dataset with the highest contributions by most of POPs: pp'DDT (15.85\%), $\mathrm{pp}^{\prime} \mathrm{DDD}(15.34 \%)$, PCBs (14.74\%), $\alpha-\mathrm{HCH}(14.67 \%)$, $\mathrm{pp}^{\prime} \mathrm{DDE}(14.18 \%)$ and $\gamma$-HCH $(12.74 \%)$, while the second component accounted for $22.13 \%$ of the variance mainly associated with HCB $(30.80 \%)$, lipids (30.05\%) and $\beta$-HCH $(20.73 \%)$.

Tevere eels were a distinct cluster (Fig. 2) characterized by the highest levels of PCBs, $p^{\prime}$ DDD, pp'DDT, HCB and $\beta$-HCH (ANOVA, $p<0.05$ ). Lesina eels were the least polluted (ANOVA, $p<0.05$ ), while Caprolace eels were characterized by the greatest heterogeneity and two subgroups could be distinguished: one, partially overlapping with Lesina eels, composed of individuals with higher lipid content and lower POP levels than those constituting the second distinct cluster (Fig. 2). In Caprolace eels, both lipid content and condition factor were negatively correlated with POP levels on lipid basis, with exception of $\beta-\mathrm{HCH}(n=22$; lipids-PCBs: $\quad r=-0.60 ; \quad$ lipids-DDTs: $\quad r=-0.73$; K-PCBs: $r=-0.65$; K-DDTs: $r=-0.75 ; p<0.05$ ).

The PCB congener profile was rather similar in eels from the three study sites; the greatest contribution to PCB contamination was by hexachlorobiphenyls 153 and 138 (>10\%), followed by pentachlorobiphenyl 118 and heptachlorobiphenyls 180 and 187 (>5\%) (Fig. 3). Penta-, hexa- and hepta-Cl PCBs accounted for more than $80 \%$ of the total PCBs, while the sum of 7 indicator PCBs amounts to $74.1 \pm 4.7 \%, 61.3 \pm 5.1 \%$ and $61.6 \pm 5.9 \%$ of the total PCBs for Caprolace, Lesina and Tevere eels, respectively.

In all the silver eels analyzed for PCDD and PCDF determination, results were below the detection limit. DLPCB concentrations, reported in Table 2 as Total TEQ, were the highest in Tevere eels (ANOVA, $p<0.05$ ).

Prevalence of A. crassus was nearly $70 \%$ in Tevere eels, $25 \%$ in Lesina eels, while no parasites were found in eels from Caprolace Lake (Table 1). Mean intensity was higher in Tevere eels $(3.27 \pm 2.43$; $\max =9)$ than in Lesina eels $(2.71 \pm 1.89$; $\max =5)$, but the difference was not statistically significant (ESM $1 ; t$ test, $p=0.60$ ).

The analysis of the infected Tevere eels (ESM 1), with the exception of the encysted ones, showed that infection
Fig. 2 Principal component analysis biplot for describing analyzed contaminants and grouping eels from the three sampling sites (Caprolace eels: blue square, Lesina eels: green triangle and Tevere eels: red circle). The horizontal axis represents the first component, the vertical axis represents the second component (Color figure online)

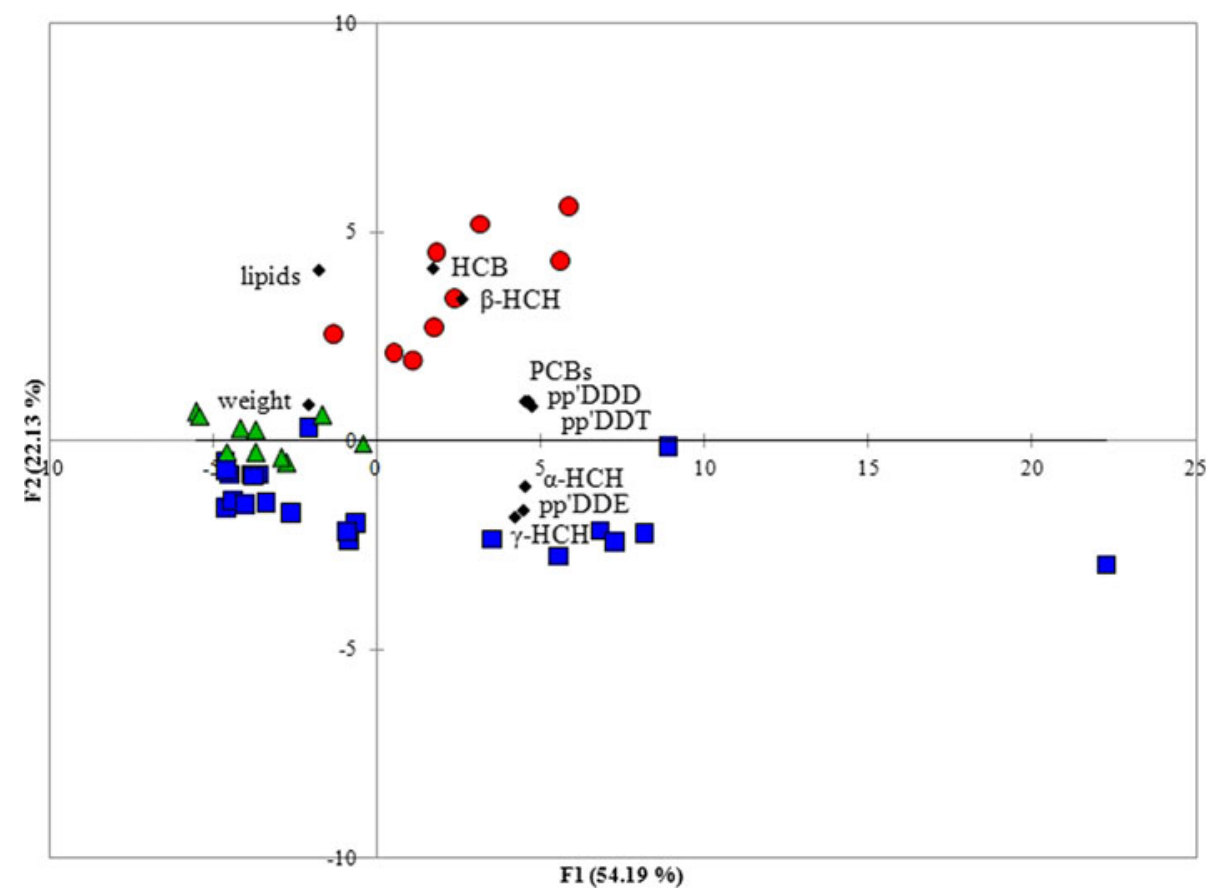


Fig. 3 Mean distribution (\%) of PCB homologues $(+\mathrm{SD})$ in the three sampling stations

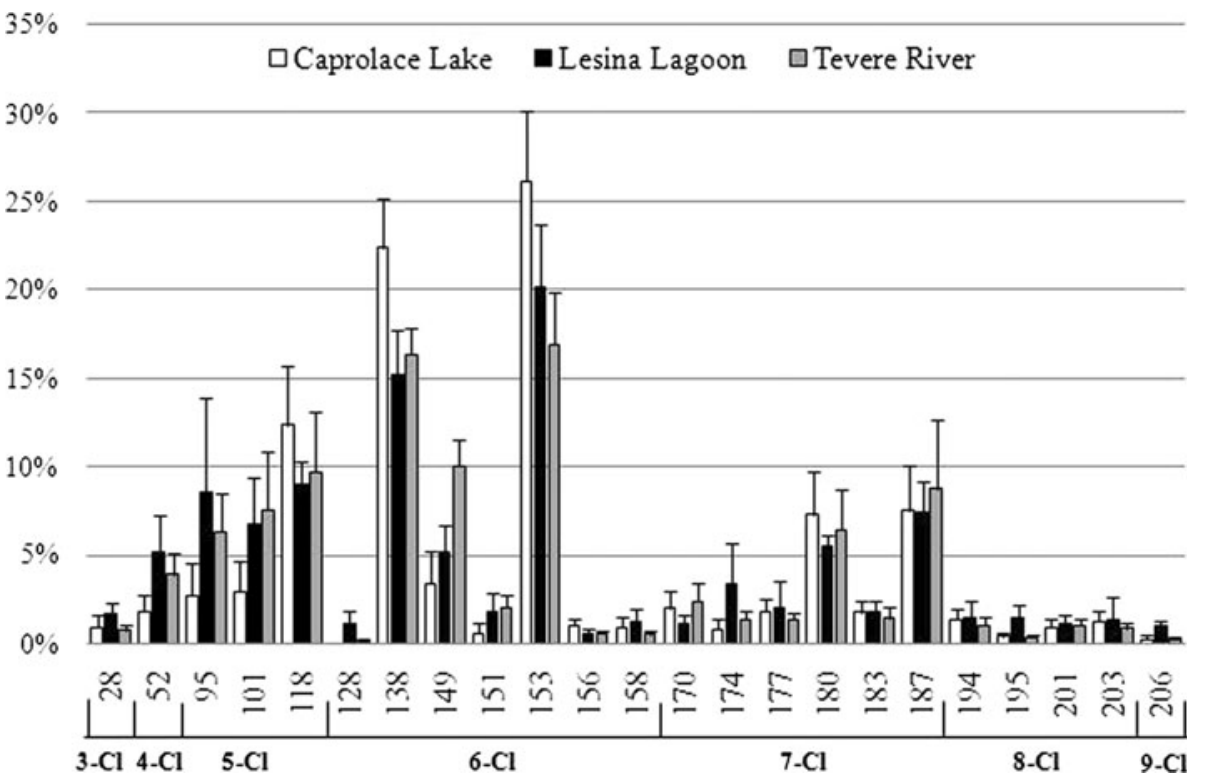

Table 2 Morphometric and physiological characteristics, DL-PCB TEQ values (pg/g w.w.), calculated using TEF values for human (van den Berg et al. 2006), of three silver eels for each study area

\begin{tabular}{|c|c|c|c|c|c|c|c|c|c|c|}
\hline \multirow[b]{2}{*}{ Sample } & & \multicolumn{3}{|c|}{ Caprolace Lake } & \multicolumn{3}{|c|}{ Lesina Lagoon } & \multicolumn{3}{|c|}{ Tevere River } \\
\hline & & 1 & 2 & 3 & 1 & 2 & 3 & 1 & 2 & 3 \\
\hline Length (cm) & & 60.0 & 35.4 & 36.0 & 70.5 & 72.5 & 56.0 & 44.0 & 41.0 & 48.5 \\
\hline Weight (g) & & 360.3 & 78.4 & 65.4 & 762.0 & 711.2 & 370.7 & 144.8 & 107.4 & 181.2 \\
\hline Sex & & ㅇ & $\hat{o}$ & $\hat{o}$ & o & 우 & o & $\hat{0}$ & $\hat{\sigma}$ & $\hat{0}$ \\
\hline Lipids (\%) & & 15.96 & 11.50 & 16.34 & 24.49 & 20.81 & 24.20 & 26.44 & 16.01 & 25.71 \\
\hline Non-ortho PCBs & WHO-TEFs 2006 & & & & & & & & & \\
\hline 81 & 0.0003 & 0.00349 & 0.00035 & 0.00032 & 0.00012 & 0.00016 & 0.00026 & 0.01347 & 0.00884 & 0.00432 \\
\hline 77 & 0.0001 & 0.00029 & 0.00002 & 0.00004 & 0.00002 & 0.00015 & 0.00045 & 0.00003 & 0.00006 & 0.00006 \\
\hline 126 & 0.1 & 2.00377 & 0.27189 & 1.13981 & 1.40450 & 1.52455 & 2.29541 & 1.71452 & 2.12983 & 2.18776 \\
\hline 169 & 0.03 & 0.01921 & 0.05745 & 0.03041 & 0.01069 & 0.01955 & 0.03889 & 2.35403 & 1.04097 & 1.72898 \\
\hline Mono-ortho PCBs & WHO-TEFs 2006 & & & & & & & & & \\
\hline 105 & 0.00003 & 0.00662 & 0.00122 & 0.00554 & 0.00005 & 0.00026 & 0.00049 & 0.00121 & 0.00708 & 0.05171 \\
\hline 114 & 0.00003 & 0.00014 & 0.00011 & 0.00010 & 0.00009 & 0.00009 & 0.00008 & 0.00005 & 0.00007 & 0.00335 \\
\hline 118 & 0.00003 & 0.07111 & 0.01661 & 0.00379 & 0.00398 & 0.00317 & 0.00770 & 0.20310 & 0.02139 & 0.15451 \\
\hline 123 & 0.00003 & 0.00109 & 0.00022 & 0.00006 & 0.00009 & 0.00026 & 0.00101 & 0.00379 & 0.00404 & 0.00260 \\
\hline 156 & 0.00003 & 0.00531 & 0.00131 & 0.00062 & 0.00044 & 0.00031 & 0.00060 & 0.02614 & 0.02337 & 0.02025 \\
\hline 157 & 0.00003 & 0.00090 & 0.00042 & 0.00021 & 0.00010 & 0.00002 & 0.00008 & 0.00383 & 0.00389 & 0.00369 \\
\hline 167 & 0.00003 & 0.00383 & 0.00046 & 0.00036 & 0.00003 & 0.00010 & 0.00042 & 0.01064 & 0.00862 & 0.00903 \\
\hline 189 & 0.00003 & 0.00061 & 0.00010 & 0.00009 & 0.00001 & 0.00003 & 0.00004 & 0.00771 & 0.00224 & 0.00246 \\
\hline TEQs & & 2.12 & 0.35 & 1.18 & 1.42 & 1.55 & 2.35 & 4.34 & 3.25 & 4.17 \\
\hline
\end{tabular}

level was positively correlated to intensity $(n=15$, $r=0.57, p<0.05)$ and negatively correlated with swim bladder length $(n=15, r=-0.54, p<0.05)$. Tevere silver males (Table 3 ) with the highest parasite abundance and infection level tended to exhibit high PCB and $\mathrm{pp}^{\prime} \mathrm{DDT}$ concentrations and low lipid content, but the correlations were not significant ( $n=7$; abundance-PCBs: $r=0.70$, $p=0.08 ;$ infection level-PCBs: $r=0.60, \quad p=0.15$; infection level-pp'DDT: $r=0.70, \quad p=0.08$; parasite abundance-lipid content: $r=-0.66, p=0.11$ ).

The histological analysis showed that eels collected in Tevere River had mainly undifferentiated gonads $(35.3 \%)$ and Syrski organs (46.0\%). Among eels with sexually differentiated gonads, males were largely prevalent over 
Table 3 Male silver eels from Tevere River analysed individually for POP determination: number (n) and weight of parasites (Wp), swim bladder length (Ls), damage $(\mathrm{Ls} / \mathrm{L})$ and infection level $(\mathrm{Wp} / \mathrm{W})$,
Gonad Alteration Level (GAL) and PCB, pp'DDE, $p^{\prime}$ DDD and $\mathrm{pp}^{\prime} \mathrm{DDT}$ concentrations on lipid basis

\begin{tabular}{|c|c|c|c|c|c|c|c|c|c|c|c|}
\hline Sample & $n$ parasites & Wp (g) & Ls $(\mathrm{cm})$ & Damage & Infection $* 10^{4}$ & GAL & $\begin{array}{l}\text { Lipids } \\
(\%)\end{array}$ & $\begin{array}{l}\text { PCBs } \\
\text { (ng/g lip.) }\end{array}$ & $\begin{array}{l}\text { pp }^{\prime} \mathrm{DDE} \\
\text { (ng/g lip.) }\end{array}$ & $\begin{array}{l}\text { pp }^{\prime} \text { DDD } \\
\text { (ng/g lip.) }\end{array}$ & $\begin{array}{l}\mathrm{pp}^{\prime} \mathrm{DDT} \\
\text { (ng/g lip.) }\end{array}$ \\
\hline 1 & 2 & 0.0006 & 4.96 & 0.11 & 0.04 & 1 & 26.44 & 1301.52 & 321.14 & 107.20 & 39.73 \\
\hline 2 & 9 & 0.4134 & 3.49 & 0.09 & 44.65 & 3 & 17.26 & 1761.69 & 454.89 & 154.80 & 113.57 \\
\hline 3 & 7 & 0.0282 & 3.97 & 0.10 & 2.96 & 2 & 18.32 & 1266.56 & 297.36 & 65.82 & 40.27 \\
\hline 4 & 4 & 0.1625 & 4.99 & 0.12 & 15.13 & 1 & 16.01 & 1011.48 & 274.35 & 70.09 & 56.64 \\
\hline 5 & 2 & 0.0046 & 6.01 & 0.13 & 0.29 & 0 & 24.23 & 1177.23 & 336.98 & 93.36 & 47.94 \\
\hline 6 & 1 & 0.0308 & 3.98 & 0.10 & 2.32 & 3 & 37.40 & 1281.22 & 1024.16 & 154.85 & 102.41 \\
\hline 7 & 0 & 0 & 3.99 & 0.10 & 0 & 2 & 23.40 & 392.41 & 218.26 & 70.30 & 41.78 \\
\hline 8 & Encysted & - & 7.00 & 0.14 & - & 2 & 25.70 & 1373.02 & 286.18 & 103.88 & 78.42 \\
\hline
\end{tabular}

females $(92.8 \%)$; nevertheless the initial stages of differentiation exhibited female features. Lesina and Caprolace eels were mainly females (75.8 and $49.5 \%$, respectively), in agreement with the comparison between the average length and weight of eels belonging to the over $40 \mathrm{~cm}$ size class from the three study sites (Table 1; ANOVA, $p<0.05$ ).

In eels from Tevere River, 19 out of 53 undifferentiated gonads showed GAL 1. Among the 69 Syrski organs, 26 had GAL 1 (Fig. 4c), 13 GAL 2 (Fig. 4d) and 9 GAL 3. Among the 25 testes, 7 showed GAL 1, 6 GAL 2 (Fig. 4e) and 5 GAL 3 (Fig. 4f). No alterations were detected in the two ovaries found. In eels from Lesina Lagoon, 4 out of 23 Syrski organs showed GAL 1. No alterations were detected in the 76 ovaries and in the only undifferentiated gonad found. In eels from Caprolace Lake, 3 out of 23 Syrski organs showed GAL 1 . Among the 25 testes, 2 had GAL 1. No alterations were detected in the 49 ovaries and 2 undifferentiated gonads found.

Concerning the eels sampled for POP determination, among 24 Tevere individuals (Table 1), one of the four undifferentiated gonads showed GAL 1. More severe alterations were found in all Syrski organs: 2 eels with GAL 1 (Fig. 4c), 4 with GAL 2 (Fig. 4d) and 3 with GAL 3. Among testes, one was normal and all others showed alterations: 3 with GAL 1, 3 with GAL 2 (Fig. 4e) and 3 with GAL 3 (Fig. 4f). The only ovary found was normal. Among the 28 eels from Lesina Lagoon (Table 1), only one (a Syrski organ) showed GAL 1. Among the 22 eels from Caprolace Lake (Table 1), only one (a testis) showed GAL 1.

Considering infected Tevere eels (ESM 1), with the exception of the encysted ones, a significant positive correlation between GAL and parasite weight $(n=15$, $\rho=0.62, p<0.05)$ and a negative correlation between GAL and Ls/L ratio $(n=15, \rho=-0.58, p<0.05)$ were found. Considering Tevere male silver eels in Table 3, correlations between GAL and POP concentrations were not significant, the highest $\rho$ value and the lowest $p$ value being that between GAL and $\mathrm{pp}^{\prime} \mathrm{DDT}(n=8, \rho=0.60$, $p=0.14)$.

\section{Discussion}

Lipid content

Our analysis showed that eels caught in winter in Caprolace Lake were older and thinner than those of the same sex and size from Tevere River and Lesina Lagoon. Significant geographical variations in fat content are common in eels and have been described earlier: Belpaire et al. (2009) recently reported considerable variation between sites both in Belgium and in The Netherlands, with minimum values of the mean lipid content per site similar to those found in Caprolace Lake. Eels from other Italian environments such as Orbetello and Santa Giusta lagoons (Mariottini et al. 2006) and Garigliano River (Ferrante et al. 2010) showed fat percentages similar to those reported for Lesina and Tevere eels. The low growth rate and condition of Caprolace eels may be explained by the extremely low productivity and the comparatively limited resources in the winter season of these salinized waters (Edeline and Elie 2004; Cairns et al. 2009). Other causes should be excluded, as parasite infection was absent and pollution was not particularly high in this group.

Food paucity in Caprolace Lake adversely affected yellow eels substantially more than silver ones: lipid content was $\leq 2 \%$ in half of the yellow specimens while exceeded $10 \%$ in all silver muscle tissues, even though it was always below $20 \%$ for all specimens and below $15 \%$ for two silver females. Although lipid content in starving fish might be underestimated (Bettinetti et al. 2011), the difference between yellow and silver eels is evident and in 

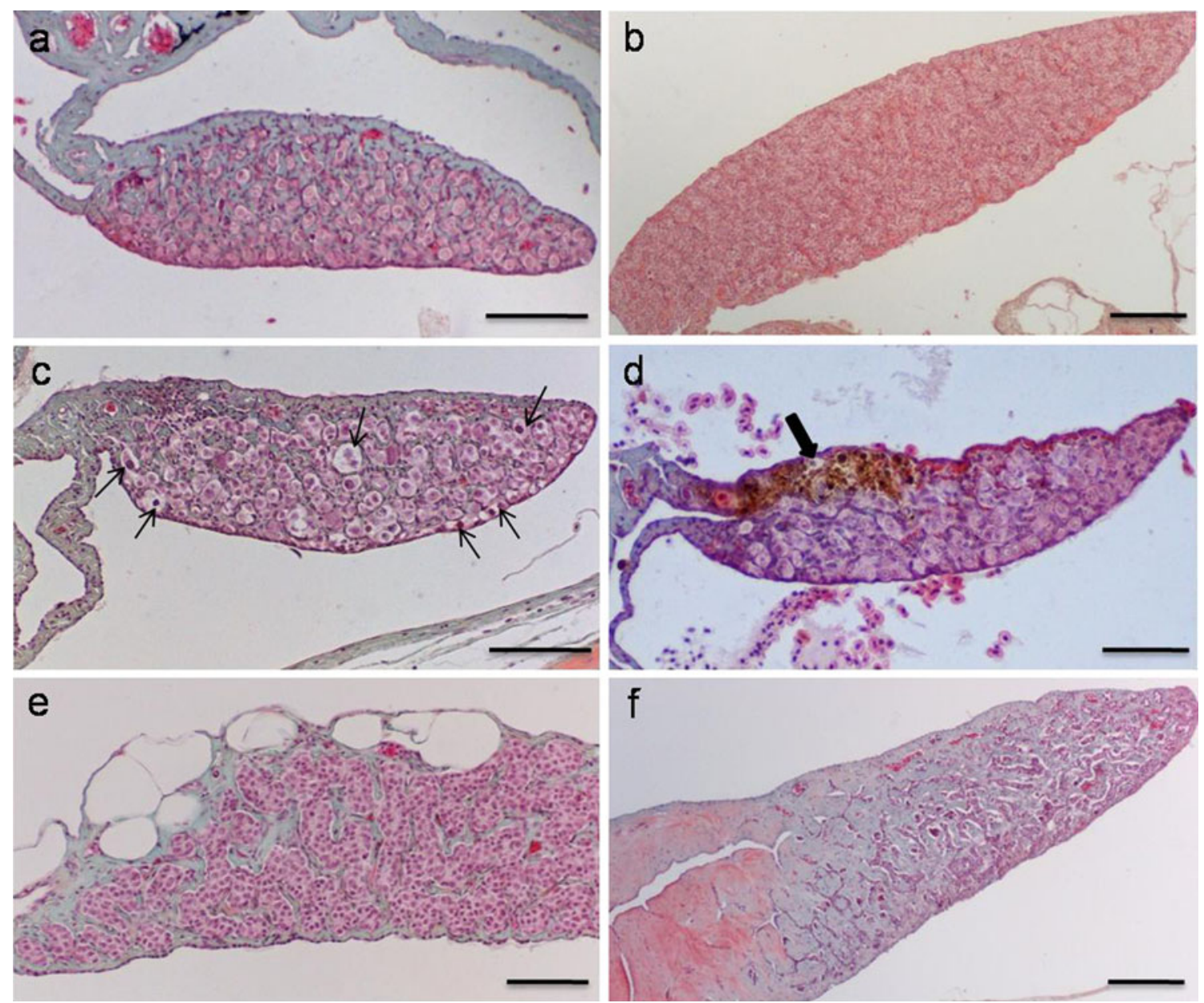

Fig. 4 Cross sections of gonads from eels of Tevere River without structural alterations (a and b) and with alterations (c, $\mathbf{d}, \mathbf{e}$ and $\mathbf{f}$ ). a Syrski organ from a $27.8 \mathrm{~cm}$ yellow eel showing normal histological structure (scale bar $100 \mu \mathrm{m}$ ). b Testis from a $46.5 \mathrm{~cm}$ silver eel showing normal histological structure (scale bar $500 \mu \mathrm{m}$ ). c Syrski organ from a $29.2 \mathrm{~cm}$ yellow eel showing Gonad Alteration Level (GAL) 1 (some degenerations of germ cells) (thin arrows) (scale bar

agreement with the fact that yellow eels are still growing while silver eels are developing or conserving lipid reserves for migration (Durif et al. 2005). Boetius and Boetius (1980) argued that lipid storage needs to be at least $20 \%$ of the body weight to support the energetic costs of migration and gamete production for this species. Van den Thillart et al. (2004) argued that energy reserves may be insufficient to reach the Sargassum Sea when fat level drops below $15 \%$ of the body weight. If this is the case, Caprolace silver eels might have minimal chances of successfully migrating to the spawning area.

\section{Parasite infection}

Palstra et al. (2007) observed that significant swim bladder damage resulted from heavy infection, i.e. when more than

$100 \mu \mathrm{m})$. d Syrski organ from a $25.8 \mathrm{~cm}$ yellow eel showing GAL 2 (a large region of necrotic tissue) (thick arrows) (scale bar $50 \mu \mathrm{m}$ ). e Testis from a $42.3 \mathrm{~cm}$ silver eel showing GAL 2 (some areas of adipose tissue, top of the figure) (scale bar $200 \mu \mathrm{m}$ ). f Testis from a $44.3 \mathrm{~cm}$ silver eel showing GAL 3 (extended hypertrophy of the connective tissue, reduced number of germ cells and loss of testis histological organization) (scale bar $500 \mu \mathrm{m}$ )

5 parasites were present. This also seems to be true in the present study, as parasite infection was associated with a reduction of swim bladder length. As swim bladder damages may significantly impair eel swimming ability (Palstra et al. 2007; Sjoberg et al. 2009), it is likely that heavily infected eels from Tevere River are unable to reach the spawning ground to contribute to recruitment.

The relation between parasite abundance and lipid content was negative but not significant. This is in accordance with other published studies that failed to verify a relationship between infection level and yellow eel condition (Kelly et al. 2000; Machut and Limburg 2008). Nonetheless, it is known that nematodes are capable of inducing stress in eels and increasing cortisol plasma levels (Sures et al. 2001). This should theoretically lead to an increase in metabolism, potentially affecting energy 
accumulation (Robinet and Feunteun 2002). In the present case, the lack of significance in the relationship between parasite abundance and lipid content may reflect the actual absence of effects by parasitic load on eel condition or it may be just a consequence of the limited sample size (i.e. only 7 specimens) used to test this relationship.

Our study provided evidence of a positive correlation between parasite weight and swim bladder damage and gonad alteration level. This result raises the possibility that parasite induced stress negatively affects gonad development. However, we cannot rule out that the observed correlations might be spurious, driven by a third variable, such as POPs and/or other contaminants, directly causing gonad abnormalities and indirectly affecting an increase of parasite infection. Our results showed that PCBs and $\mathrm{pp}^{\prime} \mathrm{DDT}$ were correlated with parasite abundance and infection level, but these relationships were just above the $5 \%$ significance level, possibly as a consequence of the limited sample size.

The absence of A. crassus in Caprolace eels is probably explained by the high salinity of the lake that makes this water body an unsuitable environment for parasite development and transmission (De Charleroy et al. 1989; Kirk et al. 2000).

\section{POP contamination}

The high variability of eel contamination levels observed in the present study probably reflects both between-site differences in land use and protection levels and within-site small-scale habitat heterogeneity (Bettinetti et al. 2011). We found a negative correlation between POP concentrations on lipid basis and lipid content in the 22 Caprolace eels. The overall amount of contaminants in these eels did not depend on the lipid content. This is somewhat surprising, since, in general, specimens with higher fat percentage may be expected to exhibit also higher accumulation of lipophilic chemicals. It is possible that POPs concentrate in Caprolace eels while lipids are metabolized in starving specimens during the winter period. This mechanism would be similar to that described by Larsson et al. (1990) for fasting eels during migration to the spawning ground.

In this study $\mathrm{pp}^{\prime} \mathrm{DDE}$ is the dominant chlorinated pesticide in eels. Although it is well recognized that this compound is a powerful anti-androgen (Kelce et al. 1995) affecting development, reproduction and sexual behaviour by causing feminization (Zhang and $\mathrm{Hu} 2008$; Bayley et al. 2002), little is still known about its effects on eels. A study on Baltic herring (Clupea harengus) found that ovarian $\mathrm{pp}^{\prime}$ DDE levels above $18 \mathrm{ng} / \mathrm{g}$ w.w. are significantly associated with reduced hatching viability (Matthiessen 2003). As interspecific differences clearly exist (Carlson et al.
2000; Foster et al. 2001), pp'DDE effects on eels cannot be simply extrapolated from studies on other species.

$\mathrm{HCB}$ and $\mathrm{HCH}$ isomers occurred at low concentrations in all the samples and are unlikely to cause adverse effects on eels. $\beta$-HCH concentrations in Tevere eels were surprisingly higher than those of lindane $(\gamma-\mathrm{HCH})$ : in fact, $\beta$ $\mathrm{HCH}$ production and use were banned since 2001 in Italy while lindane is still presently used. Our conjecture is that the higher $\beta$-HCH concentrations in Tevere eels may be due to a point pollution source: high levels of $\beta-\mathrm{HCH}$ were found in 2005 in the milk of cows farmed in the same region (Sacco River valley, Latium; ASL 2008) and more recently in the water withdrawn from some wells in the same area. Thus, $\beta$-HCH contamination could be the consequence of improperly managed wastes produced by a local chemical industry and accidentally discharged in the environment during the second half of the nineteen century.

The bioaccumulation pattern of PCBs in eels observed in this study is consistent with others previously reported both for eels and for other fish or aquatic organisms (Bordajandi et al. 2003; Mariottini et al. 2006; Storelli et al. 2007) and it is generally correlated with the degree of chlorination, the stereochemistry and the lipophilicity of the different congeners (Fox et al. 1994).

Some PCBs may reduce the spawning success of Anguilla anguilla by interfering with the ovarian development (Robinet and Feunteun 2002; Corsi et al. 2005). Levels above $120 \mathrm{ng} / \mathrm{g}$ w.w. of PCBs in ovaries of Baltic flounder (Platichthys flesus) and Baltic herring (Clupea harengus) were correlated with impaired egg development and fry survival (Matthiessen 2003). It is thus remarkable that $86 \%$ of Tevere eels exceeded this threshold in muscle tissues: according to investigations by Svobodová et al. (2003) on common carp and by Palstra et al. (2006) on the European eel, PCB concentration in eel ovary should be similar or even higher than in muscle. The impact of PCB contamination on reproductive success of Tevere eels could be significant.

Palstra et al. (2006) observed that DL-PCBs caused disrupting effects on development and survival of eel embryos below $4 \mathrm{pg} \mathrm{TEQ} / \mathrm{g}$ gonad, which is the concentration found in the muscle of the three analyzed Tevere eels. Negative consequences of DL-PCBs on reproduction should be expected for the most polluted individuals of Tevere stock, as DL-PCBs accumulated in muscle fats are also incorporated in oocytes of the mature eels. In a recent study (Miniero et al. 2011), TEQ values of 11.8, 17.5 and 21.3 were measured in three different pools of eels collected in the urban tract (Rome) of Tevere River, several times higher than those found in this study. In addition, long term adverse effects caused by DL-PCBs cannot be excluded for Caprolace and Lesina eels with TEQ levels 
higher than $1 \mathrm{pg}$ TEQ/g w.w., the lowest value at which Palstra et al. (2006) documented reproduction impairment.

Although high POP levels may cause changes in gonad histology and alterations of fish tissue structure (Louiz et al. 2009), in Tevere eels the relations between pollutant concentrations and GAL were not significant, probably because of the complexity of the contaminant mixture in the natural environments and/or to the small sample size.

Besides reproductive failure, $\mathrm{POPs}$ - endocrine disruptors in particular-might cause negative effects on the immune system and may be associated with an increased sensitivity to infectious diseases and parasites (Robinet and Feunteun 2002; Lawrence and Elliot 2003). In field studies, increased infection and disease incidence in benthic fish from various coastal areas has been associated with PCB contamination (Vethaak and Reinhalt 1992). In the case of eel, Sures and Knopf (2004) showed that a dose of $100 \mathrm{ng} / \mathrm{g}$ w.w. of PCB 126 suppress antibody response, thus increasing vulnerability to infection by $A$. crassus. Machut and Limburg (2008) found elevated infection rates when urbanized lands exceeded $15 \%$ of the tributary catchment area, as in the case of the lower Tevere River, and suggested that urbanization may increase eel susceptibility to infection by increasing stressors. The relation between PCB concentration and parasite abundance in Tevere eels was positive but not significant, probably because of the limited sample size. Even though we did not determine POP levels in swim bladder nematodes, there was no evidence that the highest infected eels were the least polluted and, on the basis of this result, we believe that bioaccumulation of the investigated contaminants did not occur in the parasites.

\section{Risk for eel predators and human consumption}

The risk for eel consumers, such as otters, fish-eating birds and humans, should not be ruled out due to the potential for POP biomagnification. The Eurasian otter (Lutra lutra) has declined significantly since 1970 in Western and Central Europe, and it is believed that this decline partially occurred as a consequence of the increasing contamination of the aquatic ecosystems (Kruuk and Conroy 1996). $86 \%$ of Tevere eels and one Caprolace specimen exceeded the less protective PCB concentration of $145 \mathrm{ng} / \mathrm{g}$ w.w. (Boscher et al. 2010) considered critical for otter survival, while all Tevere and $18 \%$ of Caprolace samples exceeded the more protective value of $25 \mathrm{ng} / \mathrm{g}$ w.w. (Boscher et al. 2010) for long-term otter conservation. According to the Great Lakes Water Quality Agreement (GLWQA 1987) PCB and DDT concentrations in fish tissues should not exceed $100 \mathrm{ng} / \mathrm{g}$ w.w. and 1,000 ng/g w.w., respectively, for the protection of fish-eating birds and other vertebrates. In this study DDTs never exceeded the proposed limit, while PCBs should constitute a risk for eel predators.
The European eel is a valuable and popular gastronomic delicacy in several Italian regions from North to South. Therefore, high contamination levels of eels may significantly contribute to increased human health risk (Belpaire and Goemans 2007; Maes et al. 2008). Our analysis showed that $36 \%$ of eels from Tevere River and $20 \%$ of those collected in Lesina Lagoon (all specimens less than $40 \mathrm{~cm}$ long) exceeded the sanitary limits of DDTs for human consumption in Italy (50 ng/g w.w. DDTs for fish with lipid content $<5 \% ; 100 \mathrm{ng} / \mathrm{g}$ w.w. for lipid content 5-20\%; $150 \mathrm{ng} / \mathrm{g}$ w.w. for lipid content $20-40 \%$; OM 1990), while none exceeded the Italian sanitary limits for HCB and HCHs (DM 1998). Only the pool of smallest eels from Tevere River exceeded the limit of $300 \mathrm{ng} / \mathrm{g}$ w.w. recently set up for the six indicator non DL-PCBs by the European Union (EU 2011). As DL-PCBs, none of the nine analyzed silver eels exceeded $10 \mathrm{pg} \mathrm{TEQ} / \mathrm{g}$ w.w. (EU 2011) even if the estimated TEQs for the most polluted specimens should exceed the sanitary limit since the ratio between total PCBs and TEQs is usually constant within the same ecosystem. This observation is supported by a recent study in which the maximum allowed concentration was exceeded by eels collected in the urban (Rome) tract of Tevere River (Miniero et al. 2011), whose human consumption is considered dangerous.

\section{Conclusions}

Our analysis confirmed that $A$. anguilla is highly sensitive to water quality degradation as previously observed in other surveys carried out in Northern and Central Europe. Tevere eels were highly parasitized and contaminated and displayed the highest incidence and severities of reproductive organ abnormalities. At Caprolace Lake, eels were older than in Tevere River, exhibited low lipid content, low levels of contaminants, no reproductive organ abnormalities and no infections. The poor condition and older age of Caprolace eels were consistent with lack of fishing pressure, winter collection and residence in oligotrophic salinized waters where $A$. crassus life cycle is not supported; moderate contamination was not associated with any apparent gonad abnormality. The contamination level on lipid basis was inversely correlated with lipid content, a possible indication that starving eels may concentrate pollutants while consuming their fat storage. At Lesina Lagoon, eels were younger than in Tevere River and in better condition than in Caprolace Lake. They were also minimally polluted, moderately parasitized and did not exhibit gonad abnormalities. Fishing pressure may explain younger age distribution and young aged eels might partially exhibit low contamination. Yet, condition and lack of reproductive organ abnormalities suggest relatively good health. 
Tevere eels exhibited a poor health status: their high contamination and infection levels have the potential to significantly affect eel reproductive ability by causing severe damage to gonads and embryos and by reducing the chance of successful migration to the spawning area. Even though only marginally contaminated and without infection, Caprolace eels also exhibited critical health conditions because of their poor nutritional status and the lack of sufficient lipid reserves to meet the energy requirement for the transoceanic migration. On the contrary, Lesina eels could be considered in good health on the basis of their minimal contamination and infection levels. Unfortunately, these eels might also be unable to fully develop their reproductive potential as overfishing in this lagoon dramatically reduces the abundance of the future spawners.

This study thus confirms that a multiplicity of stressors may impair, independently or jointly, the reproductive ability of the European eel. Our analysis did not demonstrate a significant interaction between the intensity of infection and the contamination level in Tevere eels. Further investigation is necessary to assess whether the joint effect of these multiple stressors is simply additive or could be compensatory or synergistic. Our study clearly shows that any conservation strategy for the recovery of $A$. anguilla should be devised so as to preserve both spawner quality and abundance of this threatened species.

Acknowledgments This work was supported by the Italian Ministry of University and Scientific Research-PRIN Project 2006 (n. 2006054928): "An Integrated Approach to the Conservation and Management of the European Eel in the Mediterranean Region". Thanks are due to Dr Milvia Chicca (Department of Biology and Evolution, University of Ferrara) for the English revision of the manuscript. The authors are very grateful also to the referees and the associated editor for their constructive criticism and suggestions that helped to greatly improve the paper.

Conflict of interest The authors declare that they have no conflict of interest.

\section{References}

ASL RME (2008) ASL Roma E Dipartimento di Epidemiologia Relazione Conclusiva del 26 Novembre 2008 nell'ambito del progetto "Salute della popolazione nell'area della Valle del Sacco" DOCUP Obiettivo 2 Lazio 2000-2006, Misura I.4. "Azioni di controllo, monitoraggio e informazione ambientale", pp 79

Bayley M, Junge M, Baatrup E (2002) Exposure of juvenile guppies to three antiandrogens causes demasculinization and a reduced sperm count in adult males. Aquat Toxicol 56:227-239

Belpaire C, Goemans G (2007) The European eel Anguilla anguilla, a rapporteur of the chemical status for the Water Framework Directive? Vie Milieu 57(4):235-252

Belpaire C, Goemans G, Geeraerts C, Quataert P, Parmentier K, Hagel P, De Boer J (2009) Decreasing eel stocks: survival of the fattest? Ecol Freshw Fish 18:197-214
Belpaire C, Geeraerts C, Evans D, Ciccotti E, Poole R (2011a) The European eel quality database: towards a pan-European monitoring of eel quality. Environ Monit Assess 183:273-284

Belpaire C, Geeraerts C, Roosens L, Neels H, Covaci A (2011b) What can we learn from monitoring PCBs in the European eel? A Belgian experience. Environ Int 37(2):354-364

Bettinetti R, Galassi S, Quadroni S, Volta P, Ciccotti E, Capoccioni F, De Leo GA (2011) Use of Anguilla anguilla for biomonitoring Persistent Organic Pollutants (POP) in brackish and riverine waters in Central and Southern Italy. Water Air Soil Pollut 217:321-331

Boetius I, Boetius J (1980) Experimental maturation of female silver eels, Anguilla anguilla. Estimates of fecundity and energy reserves for migration and spawning. Dana 1:1-28

Bordajandi LR, Gòmez G, Fernàndez MA, Abad E, Rivera J, Gonzàlez MJ (2003) Study on PCBs, PCDD/Fs, organochlorine pesticides, heavy metals and arsenic content in freshwater fish species from the River Turia (Spain). Chemosphere 53:163-171

Boscher A, Gobert S, Guignard C, Ziebel J, L'Hoste L, Gutleb AC, Cauchie H-M, Hoffmann L, Schmidt G (2010) Chemical contaminants in fish species from rivers in the North of Luxembourg: potential impact on the Eurasian otter (Lutra lutra). Chemosphere 78:785-792

Bressa G, Sisti E, Cima F (1997) PCBs and organochlorinated pesticides in eel (Anguilla anguilla L.) from the Po delta. Mar Chem 58:261-266

Buet A, Banas D, Vollaire Y, Coulet E, Roche H (2006) Biomarker responses in European eel (Anguilla anguilla) exposed to persistent organic pollutants. A field study in the Vaccarès Lagoon (Camargue, France). Chemosphere 65(10):1846-1858

Bush AO, Lafferty KD, Lotz JM, Shostak AW (1997) Parasitology meets ecology on its own terms: Margolis et al. revisited. J Parasitol 83(4):575-583

Cairns DK, Secor DA, Morrison WE, Hallett JA (2009) Salinitylinked growth in anguillid eels and the paradox of temperatezone catadromy. J Fish Biol 74(9):2094-2114

Carlson DB, Curtis LR, Williams DE (2000) Salmonid sexual development is not consistently altered by embryonic exposure to endocrine-active chemicals. Environ Health Persp 108:249-255

CITES (2007) Convention on international trade in endangered species of wild fauna and flora. Consideration of proposals for amendment of appendices I and II. Fourteenth meeting of the Conference of the Parties, The Hague (Netherlands), 3-15 June 2007, pp 39

Colombo G, Grandi G (1995) Sex differentiation in the European eel: histological analysis of the effects of sex steroids on the gonad. J Fish Biol 47:394-413

Colombo G, Grandi G (1996) Histological study of the development and sex differentiation of the gonad in the European eel. J Fish Biol 48:493-512

Colombo G, Grandi G, Rossi R (1984) Gonad differentiation and body growth in Anguilla anguilla L. J Fish Biol 24:215-228

Corsi I, Mariottini M, Badesso A, Caruso T, Borghesi N, Bonacci S, Iacocca A, Focardi S (2005) Contamination and sub-lethal toxicological effects of persistent organic pollutants in the European eel (Anguilla anguilla) in the Orbetello Lagoon (Tuscany, Italy). Hydrobiologia 550:237-249

De Charleroy D, Thomas K, Belpaire C, Ollevier F (1989) The viability of the free living larvae of Anguillicola crassus. J Appl Ichthyol 5:154-156

Dekker W (2003) Did lack of spawners cause the collapse of the European eel, Anguilla anguilla? Fish Manag Ecol 10:365-376

DM 22/1/1998. Decreto Ministeriale 22 gennaio 1998. Limiti massimi di residui di sostanze attive dei prodotti fitosanitari tollerate nei prodotti destinati all'alimentazione. Gazzetta Ufficiale n. 78 del 3.04.1998 
Durif C, Dufour S, Elie P (2005) The silvering process of Anguilla anguilla: a new classification from the yellow resident to the silver migrating stage. J Fish Biol 66:1025-1043

EC (2007) European Council Regulation (EC) No 1100/2007 of 18 September 2007 establishing measures for the recovery of the stock of European eel. Official Journal of the European Union L248/17-23 of 22.9.2007

Edeline E, Elie P (2004) Is salinity choice related to growth in juvenile eel Anguilla anguilla? Cybium 28(1) suppl.:77-82

Eira C, Torres J, Miquel J, Vaqueiro J, Soares AMVM, Vingada G (2009) Trace element concentrations in Proteocephalus macrocephalus (Cestoda) and Anguillicola crassus (Nematoda) in comparison to their fish host, Anguilla anguilla in Ria de Aveiro, Portugal. Sci Total Environ 407:991-998

Esteve C, Alcaide E (2009) Influence of diseases on the wild eel stock: the case of Albufera Lake. Aquaculture 289:143-149

EU (2011) Commission Regulation (EU) No 1259/2011 of 2 December 2011 amending Regulation (EC) No 1881/2006 as regards maximum levels for dioxins, dioxin-like PCBs and non dioxin-like PCBs in foodstuffs. Official Journal of the European Union L320/18-23 of 3.12.2011

Ferrante MC, Clausi MT, Meli R, Fusco G, Naccari C, Lucisano A (2010) Polychlorinated biphenyls and organochlorine pesticides in European eel (Anguilla anguilla) from the Garigliano River (Campania region, Italy). Chemosphere 78:709-716

Feunteun E (2002) Management and restoration of European eel population (Anguilla anguilla): an impossible bargain. Ecol Eng 18:575-591

Foster EP, Fitzpatrick MS, Feist GW, Schreck CB, Yates J, Spitsbergen JM, Heidel JR (2001) Plasma androgen correlation, EROD induction, reduced condition factor, and the occurrence of organochlorine pollutants in reproductively immature white sturgeon (Acipenser transmontanus) from the Columbia River, USA. Arch Environ Contam Toxicol 41:182-191

Fox K, Zauke G, Butte W (1994) Kinetics of bioconcentration and clearance of 28 polychlorinated biphenyl congeners in zebrafish (Brachydanio rerio). Ecotoxicol Environ Safe 28:99-109

Freyhof J, Kottelat M (2008) Anguilla anguilla. In: IUCN 2008. 2008 IUCN Red List of Threatened Species. http://www.iucnredlist. org. Accessed 23 May 2010

Galassi S, Gandolfi G, Pacchetti G (1981) Chlorinated hydrocarbons in fish from the River Po (Italy). Sci Total Environ 20:231-240

Gargouri Ben Abdallah L, Maamouria F (2006) Spatio-temporal dynamics of the nematode Anguillicola crassus in Northeast Tunisian lagoons. C R Biol 329(10):785-789

Geeraerts C, Belpaire C (2010) The effects of contaminants in European eel: a review. Ecotoxicology 19(2):239-266

Genc E, Sahan A, Altun T, Cengizler I, Nevsat E (2005) Occurrence of the swim bladder parasite Anguillicola crassus (Nematoda, Dracunculoidea) in European eels (Anguilla anguilla) in Ceyhan River, Turkey. Turk J Vet Anim Sci 29(3):661-663

Grandi G, Colombo G (1997) Development and early differentiation of gonad in the European eel (Anguilla anguilla L., Anguilliformes, Teleostei): a cytological and ultrastructural study. J Morphol 231:195-216

Grandi G, Poerio F, Colombo G, Chicca M (2000) Effects of diet supplementation ovary on gonad differentiation and growth of the European eel. J Fish Biol 57:1505-1525

GLWQA, Great Lakes Water Quality Agreement (1987) www. cananglass.org. Accessed on 29 June 2011

Harrad S, Smith D (1999) Eel consumption as a pathway of human exposure to PCBs. Int J Environ Health Res 9:31-37

ICES (2001) Report of the 2000 Session of the Joint EIFAC/ICES Working Group on Eels (WGEEL), 28 August-1 September 2000, St.Andrews, N.B., Canada. ICES CM 2001/ACFM:03. pp 87
ICES (2007) Report of the 2007 Session of the Joint EIFAC/ICES Working Group on Eels (WGEEL), 3-7 September 2007, Bordeaux, France. EIFAC Occasional Paper. No. 38, ICES CM 2007/ACFM:23. pp 526

ICES (2009) Report of the 2009 Session of the Joint EIFAC/ICES Working Group on Eels (WGEEL), 7-12 September 2009, Göteborg, Sweden. ICES CM 2009/ACOM:15. pp 137

ICES (2011) Report of the 2011 Session of the Joint EIFAC/ICES Working Group on Eels (WGEEL), 5-9 September 2011, Lisbon, Portugal. ICES CM 2011/ACOM:18. pp 228

Kelce WR, Stone CR, Laws SC, Gray LE, Kemppainen JA, Wilson EM (1995) Persistent DDT metabolite $\mathrm{pp}^{\prime} \mathrm{DDE}$ is a potent androgen receptor antagonist. Nature 375:581-585

Kelly CE, Kennedy CR, Brown JA (2000) Physiological status of wild European eels (Anguilla anguilla) infected with the parasitic nematode, Anguillicola crassus. Parasitology 120:195-202

Kirk RS, Lewis JW, Kennedy CR (2000) Survival and transmission of Anguillicola crassus Kuwahara, Niimi \& Itagaki 1974 (Nematoda) in seawater eels. Parasitology 120:289-295

Kruuk H, Conroy JWH (1996) Concentrations of some organochlorines in otters (Lutra lutra L.) in Scotland: implications for populations. Environ Pollut 92:165-171

Larsson P, Hamrin S, Okla L (1990) Fat content as a factor inducing migratory behaviour in the eel (Anguilla anguilla) to the Sargasso Sea. Naturwissenschaften 77(10):488-490

Larsson P, Hamrin S, Okla L (1991) Factors determining the uptake of persistent pollutants in an eel population (Anguilla anguilla L.). Environ Pollut 69:39-50

Lawrence AJ, Elliot M (2003) Introduction and conceptual model. In: Lawrence A, Hemingway K (eds) Effects of pollution on fish: molecular effects and population responses. Blackwell Science Ltd, Oxford, pp 1-13

Lefebvre F, Crivelli AJ (2004) Anguillicolosis: dynamics of the infection over two decades. Dis Aquat Organ 62:227-232

Lefebvre F, Contournet P, Priour F, Soulas O, Crivelli AJ (2002) Spatial and temporal variation in Anguillicola crassus counts: results of a 4-year survey in eels from Mediterranean lagoons. Dis Aquat Organ 50:181-188

Lefebvre F, Acou A, Poizat G, Crivelli AJ (2003) Anguillicolosis among silver eels: a 2-year survey in 4 habitats from Camargue (Rhône delta, South of France). B Fr Pêche Piscic 368:97-108

Lefebvre F, Fazio G, Palstra AP, Szèkely C, Crivelli AJ (2011) An evaluation of indices of gross pathology associated with the nematode Anguillicoloides crassus in eels. J Fish Dis 34:31-45

Louiz I, Ben-Attia M, Ben-Hassine OK (2009) Gonadosomatic index and gonad histopathology of Gobius niger (Gobiidea, Teleost) from Bizerta Lagoon (Tunisia): evidence of reproduction disturbance. Fish Res 100:266-273

Maamouria F, Gargouri L, Ould Daddah M, Bouix G (1999) Occurrence of Anguillicola crassus (Nematode, Anguillicolidae) in the Ichkeul Lake (northeastern Tunisia). Bull Eur Assoc Fish Pathol 19:17-19

Macgregor K, Oliver IW, Harris L, Ridgway IM (2010) Persistent organic pollutants (PCB, DDT, HCH, HCB \& BDE) in eels (Anguilla anguilla) in Scotland: current levels and temporal trends. Environ Pollut 158:2402-2411

Machut LS, Limburg KE (2008) Anguillicola crassus infection in Anguilla rostrata from small tributaries of the Hudson River watershed, New York, USA. Dis Aquat Organ 79:37-45

Maes J, Belpaire C, Goemans G (2008) Spatial variations and temporal trends between 1994 and 2005 in polychlorinated biphenyls, organochlorine pesticides and heavy metals in European eel (Anguilla anguilla L.) in Flanders, Belgium. Environ Pollut 153:223-237

Maillo PA, Vich MA, Salvado H, Marques A, Gracia MP (2005) Parasites of Anguilla anguilla (L.) from three coastal lagoons of 
the River Ebro delta (Western Mediterranean). Acta Parasitol 50(2): $156-160$

Mariottini M, Corsi I, Focardi S (2006) PCB levels in European eel (Anguilla anguilla) from two coastal lagoons of the Mediterranean. Environ Monit Assess 117:519-528

Matthiessen P (2003) Endocrine disruption in marine fish. Pure Appl Chem 75(11-12):2249-2261

Miller WR, Sharpe RM (1998) Environmental estrogens and human reproductive cancers. Endocr Relat Cancer 5:69-96

Miniero R, Guandalini E, Dellatte E, Iacovella N, Abate V, De Luca S, Iamiceli AL, di Domenico A, De Felip E (2011) Persistent Organic Pollutants (POPs) in fish collected from the urban tract of the River Tiber in Rome (Italy). Annali dell' Istituto Superiore di Sanità 47(3):310-315

Möller H, Holst S, Lüchtenberg H, Petersen F (1991) Infection of eel Anguilla anguilla from the River Elbe estuary with two nematodes, Anguillicola crassus and Pseudoterranova decipiens. Dis Aquat Organ 11(3):193-199

Nash RDM, Valencia AH, Geffen AJ (2006) The origin of Fulton's condition factor-setting the record straight. Fisheries 31(5): 236-238

OM 18/07/1990. Ordinanza Ministeriale del 18/07/1990. G.U. della Repubblica Italiana No. 57 del 30.08.1990

Palstra AP, van Ginneken VJT, Murk AJ, van den Thillart GEEJM (2006) Are dioxin-like contaminants responsible for the eel (Anguilla anguilla) drama? Naturwissenschaften 93:145-148

Palstra AP, Heppener DFM, van Ginneken VJT, Székely C, van den Thillart GEEJM (2007) Swimming performance of silver eels is severely impaired by the swim bladder parasite Anguillicola crassus. J Exp Mar Biol Ecol 352:244-256

Pankhurst NW (1982) Relation of visual changes to the onset of sexual maturation in the European eel A. anguilla (L.). J Fish Biol 21:127-140

Rahhou I, Melhaoui M, Lecomte-Finiger R, Morand S, Chergui H (2001) Abundance and distribution of Anguillicola crassus (Nematoda) in eels Anguilla anguilla from Moulouya Estuary (Morocco). Helminthologia 38(2):93-97

Robinet T, Feunteun E (2002) Sublethal effects of exposure to chemical compounds: a cause for the decline in Atlantic Eels? Ecotoxicology 11:265-277

Sjoberg NB, Petersson E, Wickstrom H, Hansson S (2009) Effects of the swim bladder parasite Anguillicola crassus on the migration of European silver eels Anguilla anguilla in the Baltic Sea. J Fish Biol 74:2158-2170

Storelli MM, Barone G, Garofalo R, Marcotrigiano GO (2007) Metals and organochlorine compounds in eel (Anguilla anguilla) from the Lesina Lagoon, Adriatic Sea (Italy). Food Chem 100: 1337-1341
Sures B (2006) How parasitism and pollution affect the physiological homeostasis of aquatic hosts. J Helminthol 80(2):151-157

Sures B, Knopf K (2004) Individual and combined effects of cadmium and 3,3',4,4',5-pentachlorobiphenyl (PCB126) on the humoral immune response in European eel (Anguilla anguilla) experimentally infected with larvae of Anguillicola crassus (Nematoda). Parasitology 128:445-454

Sures B, Knopf K, Kloas W (2001) Induction of stress by the swim bladder nematode Anguillicola crassus in European eels, Anguilla anguilla, after repeated experimental infection. Parasitology 123(2):179-184

Sures B, Lutz I, Kloas W (2006) Effects of infection with Anguillicola crassus and simultaneous exposure with $\mathrm{Cd}$ and $3,3^{\prime}, 4,4^{\prime}, 5$ pentachlorobiphenyl (PCB 126) on the levels of cortisol and glucose in European eel (Anguilla anguilla). Parasitology 132:281-288

Svobodová Z, Žlábek V, Randák T, Máchová J, Kolářová J, Hajšlová J, Suchan P (2003) Profiles of Persistent Organochlorine Pollutants (POPs) in tissues of marketable common carp and in bottom sediment of selected ponds of South and West Bohemia. Acta Vet Brno 72:295-309

Székely CS, Molnár K, Rácz O (2005) Radiodiagnostic method for studying the dynamics of Anguillicola crassus (Nematoda: Dracunculoidea) infection and pathological status of the swim bladder in Lake Balaton eels. Dis Aquat Organ 64(1):53-61

Tenora F, Barus V, Kracmar S, Dvoracek J, Srnkova J (1999) Parallel analysis of some heavy metals concentrations in the Anguillicola crassus (Nematoda) and the European eel Anguilla anguilla (Osteichthyes). Helminthologia 36(2):79-81

Tesch FW (2003) In: Thorpe JE (ed) The eel, vol 65, 3rd ed. Blackwell Science Ltd, Oxford

van den Berg M, Birnbaum LS, Denison M, De Vito M, Farland W, Feeley M, Fiedler H, Hakansson H, Hanberg A, Haws L, Rose M, Safe S, Schrenk D, Tohyama C, Tritscher A, Tuomisto J, Tysklind M, Walker N, Peterson RE (2006) The 2005 World Health Organization reevaluation of human and mammalian toxic equivalency factors for dioxins and dioxin-like compounds. Toxicol Sci 93:223-241

van den Thillart G, van Ginneken V, Körner F, Heijmans R, van der Linden R, Gluvers A (2004) Endurance swimming of European eel. J Fish Biol 65:1-7

Vethaak AD, Reinhalt T (1992) Fish disease as a monitor for marine pollution: the case of the North Sea. Rev Fish Biol Fish 2:1-32

Zhang Z, Hu J (2008) Effects of p,p-DDE exposure on gonadal development and gene expression in Japanese medaka (Oryzias latipes). J Environ Sci 20:347-352 